\title{
Proses Representasi Siswa Sekolah Dasar Dalam Menyelesaikan Masalah Matematika
}

\author{
Mohammad Archi Maulyda', Muhammad Erfan ${ }^{2}$ \\ Prodi Studi PGSD Universitas Mataram ${ }^{1,2}$ \\ email: archimaulyda@unram.ac.id
}

\begin{abstract}
Abstrak
Tujuan penelitian kualitatif deskriptif ini adalah untuk melihat representasi siswa dalam menyelesaikan masalah soal cerita. Subjek penelitian adalah siswa Kelas VI SDN 1 Sombron. Subjek dipilih berdasarkan hasil soal pretes dan wawancara singkat yang dilakukan pada 28 siswa dalam 1 Kelas. Dari 28 siswa yang menjadi subjek penelitian, dipilih 2 siswa yang mewakili 2 kategori jawaban yang muncul dalam 1 Kelas. Masing-masing kategori, yakni kategori siswa yang menjawab dengan benar dan siswa yang menjawab salah diampil satu siswa secara acak untuk dianalisis lebih lanjut. Lokasi penelitian adalah SDN 1 Sombron. Subjek akan diberikan soal tes dan akan diwawancara untuk menggali informasi terkait hasil pekerjaanya. Hasil penelitian ini menunjukan bahwa masih ada siswa yang kesulitan dalam menyelesaikan masalah matematika dalm bentuk soal cerita. Penelitian ini juga menunjukan bahwa represantasi memegang peran penting dalam keberhasilan siswa menyelesaikan masalah berbentuk soa cerita.
\end{abstract}

Kata Kunci: Matematika, Polya, Representasi, Soal Cerita 


\section{PENDAHULUAN}

Matematika merupakan ilmu dasar yang mampu mendukung ilmu lain dan merupakan sarana berpikir ilmiah yang diharapkan dapat dipelajari dan dikuasi dengan baik oleh para siswa sesuai dengan tingkatan pendidikannya. Komatsu (2016) menyatakan bahwa matematika adalah ilmu tentang logika mengenai bentuk, susunan, besaran dan konsepkonsep yang berhubungan satu dengan yang lain yang terbagi kedalam tiga bidang yaitu aljabar, analisis, dan geometri. Kaur (2014) mengklaim bahwa matematika terdiri atas komponen-komponen: (1) bahasa (language), (2) pernyataan (statement), (3) pertanyaan (question), (4) alasan (reason), dan (5) ide matematika itu sendiri. Matematika memegang peranan penting dalam suatu proses pembelajaran karena seseorang akan dilatih untuk berpikir kritis, kreatif, logis, analitis, dan sistematis (The National Council of Teachers of Mathematics, 2000).

Sama halnya dengan matematika, pemecahan masalah juga merupakan hal yang penting. Kemampuan memecahkan masalah sangat diperlukan siswa dalam memahami konsep, hubungan antar konsep, dan hubungan antar konsep dengan bidang lainnya (Maulyda et al., 2020). Menurut Santoso et al. (2020) bahwa pemecahan masalah yang baik umumnya membangun representasi dari masalah untuk memudahkan pemahaman. Hal tersebut ditegaskan dengan pernyataan Sukoriyanto et al. (2016) bahwa pemecahan masalah adalah keterampilan dasar yang dibutuhkan oleh peserta didik saat ini dan pemecahan masalah menjadi fokus utama dari kurikulum matematika. Senada dengan itu Hidayati et al. (2020) menyatakan bahwa pemecahan masalah adalah "jantung" dari matematika. Menurut Maulyda et al. (2019) perumuskan langkah-langkah pemecahan masalah dapat dilakukan dengan cara; (1) Understanding the Problem atau memahami masalah, (2) Devising a Plan atau menyusun rencana, (3) Carry Out the Plan atau melaksanakan perencanaan dan (4) Looking Back atau melihat kembali.

Meskipun pemecahan masalah menjadi "jantung" dari matematika, masih banyak siswa mengalami kesulitan dalam memecakan masalah. Yusnia (2018) dalam penelitianya memaparkan bahwa siswa mengalami kesulitan dalam menyelesaikan masalah matematis yang berbentuk soal cerita. Kesulitan yang dialami antara lain memahami dan membuat generalisasi tentang keterampilan dan konsep matematika, dan konsep atau prosedur matematika (Desoete, 2019). Hal yang senada juga disampaikan Pantaleon et al. (2018) serta Jeannotte \& Kieran (2017) bahwa kesulitan siswa dalam menyelesaikan soal cerita diantaranya adalah membaca dan memahami, membaca semua informasi, informasi yang mengganggu perhatian, membayangkan konteks, menulis kalimat matematika, perhitungan dan menerjemahkan jawaban. Hal itu terjadi karena siswa tidak merepresentasikan informasi 
yang ada di dalam masalah dengan tepat. Karena pada masalah dalam bentuk soal cerita representasi yang tepat pada masalah akan mempermudah proses penyelesaian. Siswa dikatakan telah mampu memecahkan suatu masalah jika telah mampu memahami masalah, mampu merencanakan pemecahan masalah tersebut, dan mampu melakukan perhitungan serta memeriksa kembali hasil perhitungan yang telah dilakukan (Kosko \& Gao, 2017).

Pada jenjang kelas VI SDN 1 Sombron, banyak sekali materi-materi matematika yang berbentuk soal cerita. Soal cerita dipandang dapat meningkatkan kemampuan siswa dalam menyelesaikan masalah matematis (Berry et al., 2009). Hal ini dikerenakan masalah yang berbentuk soal cerita akan menuntut siswa untuk membuat analogi antara masalah dan strategi penyelesaian atau model penyelesaian. Dalam membuat analogi ini siswa harus dapat memahami masalah dengan baik. Ketika memahami sebuah permasalahan siswa harus memiliki kemampuan representasi yang baik (Walk \& Lassak, 2017). Hal ini dikarenakan kemampuan representasi seseorang akan mempengaruhi pemahaman siswa terkait masalah yang diberikan. Ketika terjadi kesalahan dalam memahami masalah yang diberikan, maka pemilihan strategi terhadap masalah juga akan salah. Akibatya hasil yang didapat juga tidak tepat. Penelitian-penelitian yang dilakukan sebelumnya hanya melihat proses pemecahan masalah siswa saja (Problem Solving). Padahal dalam langkah memahami masalah (Understand the Problem) salah satu aspek yang berperan adalah kemampuan representasi siswa. Jika pada tahap ini siswa melakukan kesalahan, maka kesalahan tersebut akan berlanjut sampai pada tahap perhitungan dan mendapatkan kesimpulan jawaban.

Melihat fakta-fakta yang telah dipaparkan, penting untuk menelusuri bagaimana representasi siswa dalam menyelesaikan masalah soal cerita menggunakan langkah-langkah polya. Penelitian ini dilakukan dengan harapan guru sebagai tenaga pendidik memiliki gambaran yang berkaitan dengan proses representasi siswa. Dengan mengetahui dimana letak kesalahan yang cenderung dilakukan siswa, guru dapat memberikan tindakan yang tepat untuk mengurangi kesalahan tersebut terjadi kembali.

\section{METODE PENELITIAN}

Penelitian ini adalah penelitian deskriftif-kualitatif yang merupakan salah satu jenis penelitian kualitatif. Sesuai dengan pendapat Creswell (2014) yang menyatakan bahwa pendekatan kualitatif merupakan prosedur-prosedur penelitian yang menghasilkan data kualitatif, ucapan atau catatan orang-orang itu sendiri atau tingkah laku mereka yang terobservasi. Penelitian jenis ini dipilih karena tujuan penelitian ini adalah ingin melihat bagaimana representasi siswa dalam menyelesaikan masalah matematis ditinjau dari langkah-langkah Polya. Lokasi penelitian adalah di kelas VI SDN 1 Sombron Nganjuk. 
Teknik pemilihan subyek pada penelitian ini adalah purposive sampling. Subjek penelitian ini adalah 28 siswa kelas VI SDN 1 Sombron. Peneliti memberikan soal tes kepada seluruh siswa dalam Kelas tersebut.

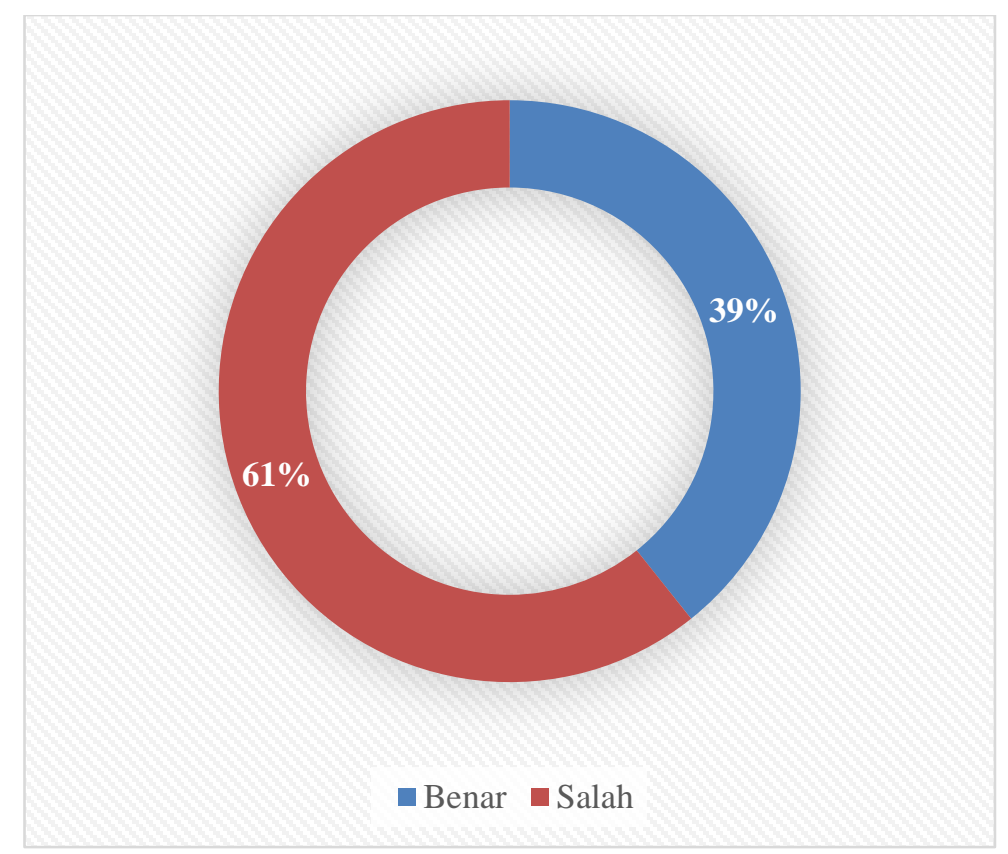

\section{Gambar 1. Hasil tes pada 28 siswa}

Berdasarkan hasil pekerjaan siswa, terdapat 11 siswa yang menjawab benar dan 17 lainya masih salah dalam menjawab soal tes. Dari siswa yang menjawab benar dan salah, peneliti mengambil masing-masing satu siswa untuk dianalisis lebih lanjut. Pemilihan ini dilakukan secara random karena melihat hasil pekerjaan siswa yang mirip, sehingga subjek dapat mewakili subjek yang lain pada masing-masing kategori. Selanjutnya, kedua subjek akan diteliti lebih lanjut representasinya. Kedua subjek diberikan kode S1 unruk subjek pertama, dan S2 untuk subjek kedua.

Dua orang subjek akan diberikan soal tes. Prosedur penyelesaian soal siswa disesuaikan dengan langkah-langkah dari Polya. Sehingga sebelum diberikan tes, subjek terlebih dahulu diajarkan tentang prosedur penyelesaian masalah yang sesuai dengan langkah-langkah Polya. Setelah mengerjakan soal tes subjek akan diwawancarai terkait hasil pekerjaanya. Wawancara yang dilakukan merupakan wawancara tidak terstruktur, dengan tujuan untuk menggali informasi terkait representasi yang dilakukan subjek dalam menyelesaikan soal. Hasil tes dan wawancara dari 2 subjek kemudian dianalisis berdasarkan indikator representasi yang telah dibuat. Berikut indikator yang dirumuskan oleh peneliti: 
Tabel 1. Indikator Representasi

\begin{tabular}{clc}
\hline Indikator Representasi & \multicolumn{1}{c}{ Bentuk Operasional } & Kode Indikator \\
\hline $\begin{array}{c}\text { Menggunakan } \\
\text { Representasi Untuk }\end{array}$ & $\begin{array}{l}\text { Memahami masalah yang } \\
\text { diberikan }\end{array}$ & $\mathrm{R} 1$ \\
\cline { 2 - 3 } & $\begin{array}{l}\text { Membuat bentuk } \\
\text { representasi untuk } \\
\text { menyelesaikan masalah }\end{array}$ & $\mathrm{R} 2$ \\
\hline
\end{tabular}

Hasil analisis pekerjaan siswa kemudian digunakan sebagai bahan pertimbangan dalam kesimpulan penelitian. Sehingga Teknik pengumpulan data yang digunakan dalam penelitian ini yaitu tes dan wawancara. Instrument yang digunakan dalam penelitian ini berupa tes urain. Soal ini merupakan hasil modifikasi dari buku paket matematika Kelas VI SD kurikulum K-13 (2016). Soal ini diberikan dengan harapan akan dapat melihat proses siswa dalam membuat model representasi matematis untuk menyelesaikan masalah. Berikut soal tes yeng diberikan kepada siswa:

Uang saku kiki Rp. 2.000,00 lebih banyak dari uang saku adiknya. Setiap hari Ibunya memberi uang setinggi - tingginya Rp. 15.000,00. Buatlah model matematika dan tentukan berapa paling banyak uang saku yang diterima kiki dan adiknya!

\section{HASIL DAN PEMBAHASAN}

Berikut hasil pekerjaan S1 dan S2 :

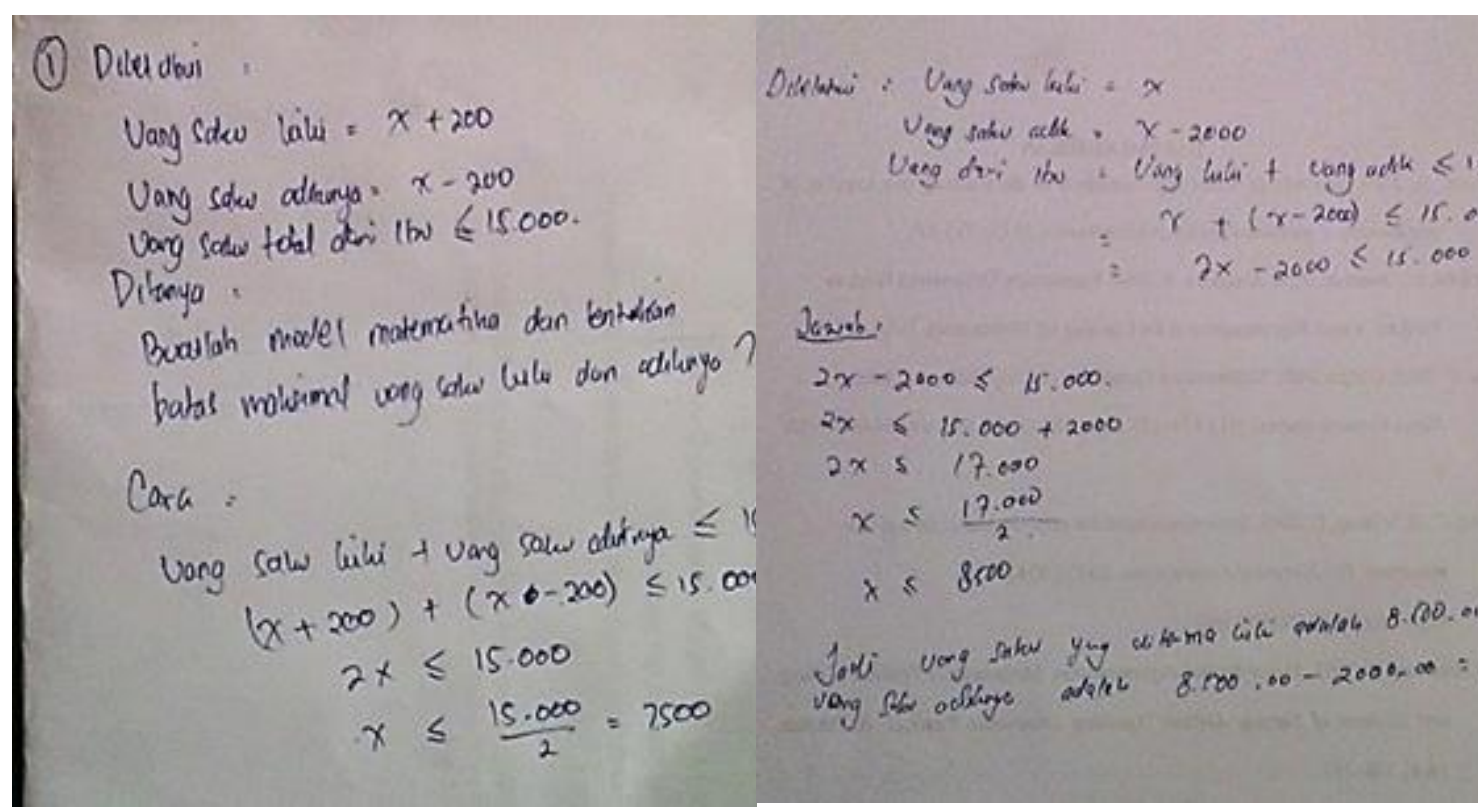

Gambar 2. Hasil Pekerjaan Subjek 1

Gambar 3. Hasil Pekerjaan Subjek II 


\section{Memahami Masalah (Understanding Problem)}

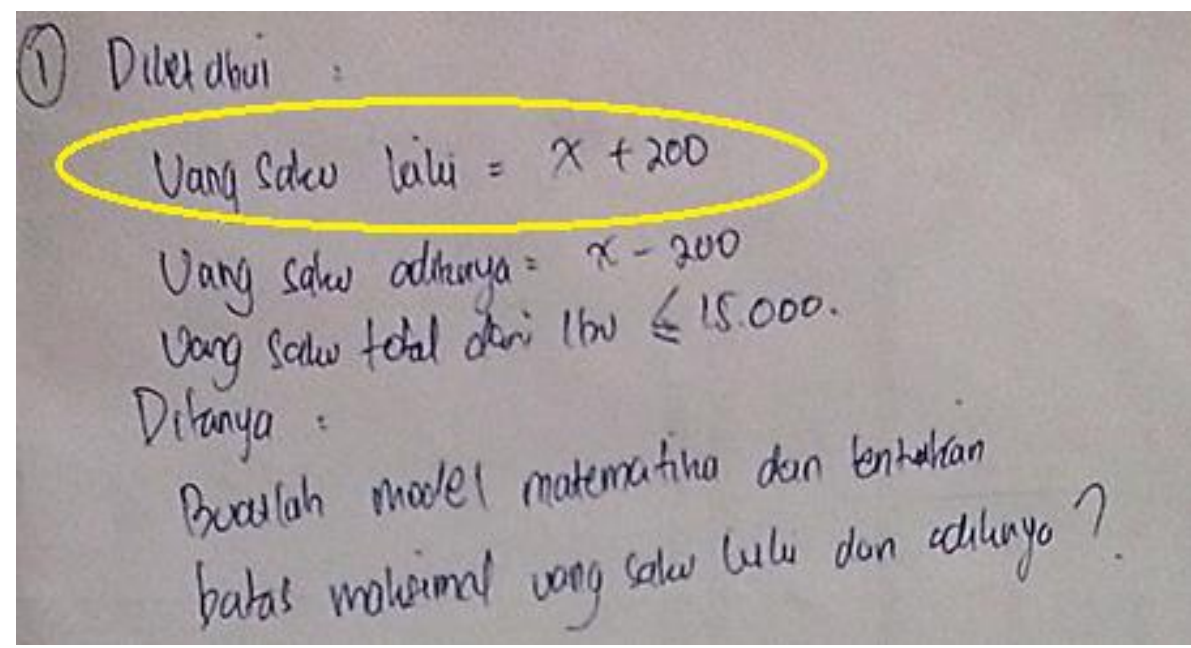

Gambar 4. Kesalahan pada tahap memahami masalah S1

Dapat kita lihat pada gambar 4, bahwa S1 telah melakukan kesalahan dalam memahami masalah. Terlihat pada lingkaran kuning, S1 salah merepresentasikan kalimat yang ada didalam soal "Uang saku kiki Rp. 2.000,00 lebih banyak dari uang saku adiknya". Kesalahan representasi juga terlihat pada hasil wawancara berikut:

$\mathrm{P}$ : “Apa maksudnya uang saku kiki sama dengan $\boldsymbol{x}+\mathbf{2 0 0 " ? ~}$

S1: " uang saku kiki kan 200 lebih banyak dari adiknya, saya misalkan $\boldsymbol{x}$ adalah uang saku, makanya jadi $\boldsymbol{x}+\mathbf{2 0 0}$ Pak, eh maksud saya 2000 pak, kurang 0”.

Dari hasil wawancara tersebut, maka dapat dilihat bahwa S1 melakukan kesalahan dalam memahami soal. Kesalahan ini dikarenakan representasi kalimat yang salah dari S1 tentang uang saku kiki. S1 menganggap bahwa kata "lebih" itu artinya adalah penjumlahan dalam model matematis, padahal kata "lebih" artinya adalah uang saku kiki lebih banyak 2000 rupiah dari kiki. Sehingga S1 tidak memenuhi indikator R1. Barata \& Pinto (2019) memaparkan bahwa, kesalahan representasi eksternal akan mengakibatkan masuknya informasi yang salah. Karena representasi yang salah dari S1, mengakibatkan informasi yang didapat juga tidak tepat. Sehingga terjadi kesalahan dalam memahami soal. Hal ini sesuai dengan penelitian yang dilakukan Morphew et al. (2020) yang menunjukan bahwa kesalahan yang paling sering dilakukan siswa dalam menyelesaikan masalah adalah memahami masalah (understanding problem). 


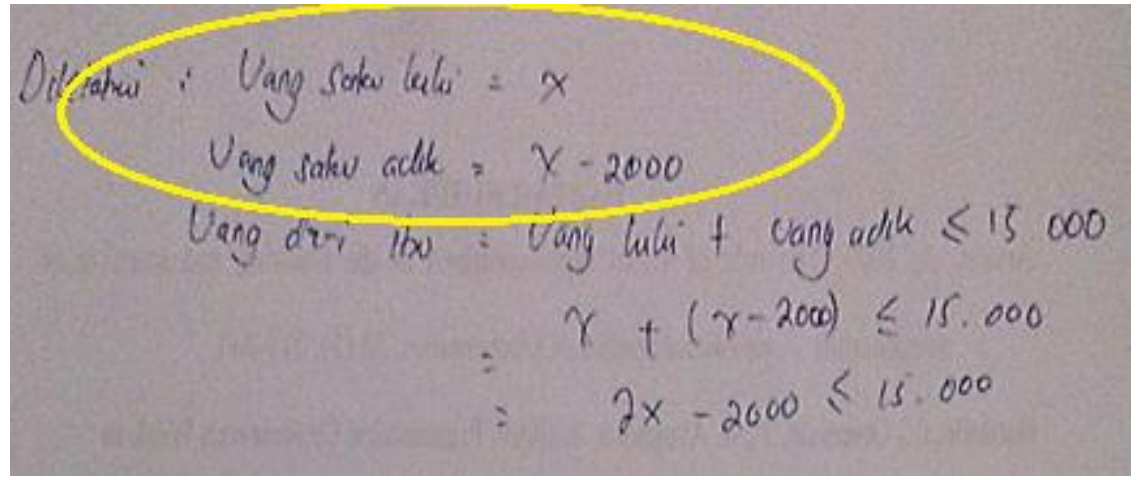

Gambar 5. Tahap memahami masalah S2

Sedangkan pada hasil pekerjaan S2, gambar 5 menunjukan bahwa S2 telah dapat merepresentasikan kalimat soal dengan baik. Terlihat pada lingkaran hitam, bahwa S2 dapat mengidentifikasi informasi yang diketahui pada soal untuk menyelesaikan soal. Berikut hasil wawancara dengan S2: $200 " ?$

$\mathrm{P}$ : "kenapa uang saku kiki sama dengan $x$ dan adiknya sama dengan $x-$

S1: “ uang saku kiki kan lebih banyak dari adinya 2000 Pak, kalo saya misalkan uang saku kiki dengan $x$ berarti uang saku adiknya kan $x-$ 2000. Artinya kan uang saku kiki lebih banyak dari adiknya Pak".

Berdasarkan hasil wawancara tersebut, dapat disimpulkan bahwa S2 telah memahami masalah dan memnuhi indikator R1.

\section{Menyusun Rencana (Devising a Problem)}

Pada gambar 6 dapat dilihat bahwa S1 sebenarnya telah membuat pertidaksamaan untuk rencana penyelesaian yang baik. Pada lingkaran kuning terlihat bahwa S1 membuat model matematika dengan merepresentasikan kalimat "setinggi-tingginya" dengan simbol " $\leq$ " yang artinya total jumlah uang saku kiki dan adikya tidak lebih dari 15.000 rupiah. Hal ini bertolak belakang dengan hasil penelitian yang dilakukan Indrianto \& Nurul Fatmawati (2020) yang memaparkan bahwa banyak anak pada jenjang kelas VI SD yang melakukan kesalahan saat menggunakan simbol pertidaksamaan. Namun dari hasil pekerjaan S1, ternyata subjek dapat merepresentasikan simbol pertidaksamaan dengan baik. Hal tersebut terlihat pada hasil wawancara berikut :

P : “ini maksudnya apa ?” (menunjukan gambar yang dilingkari kuning) 
S1: “ kan uang dari Ibu setinggi-tingginya 15.000 Pak, berarti uang saku kiki ditambah sama uang saku adiknya tidak lebih dari 15.000”.

P : "lalu setelah itu?".

S1 : " tinggal dimasukan tadi apa yang sudah diketahui Pak, berarti $(x+$ $2000)+(x-2000) "$.

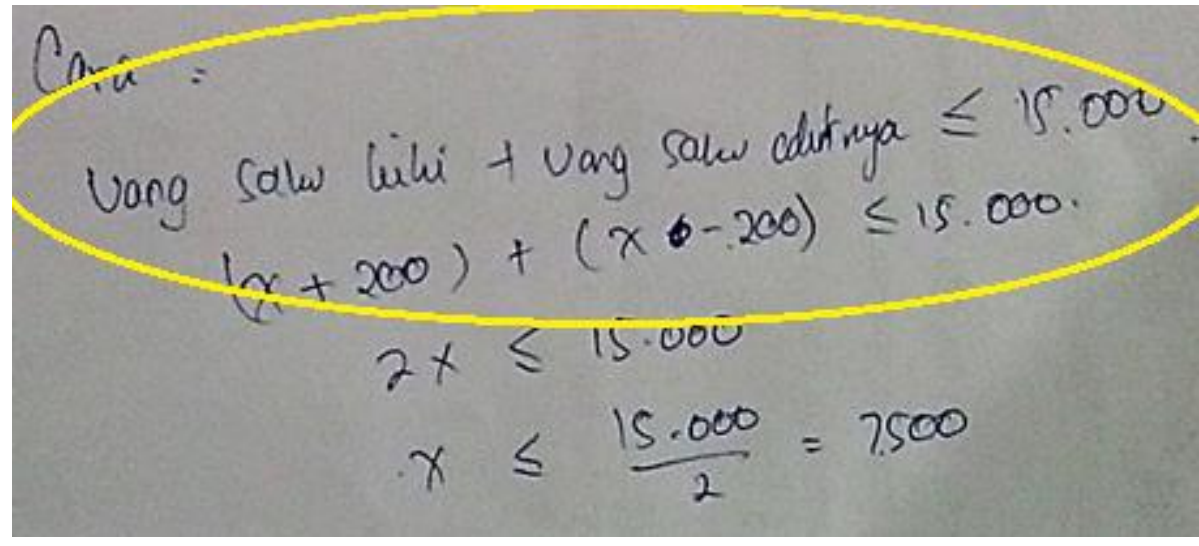

Gambar 6. Model Matematika S1

Pada langkah selanjutnya, dikarenakan terjadi representasi yang salah saat memahami "uang saku kiki" akibatnya model matematis yang dibuat S1 juga tidak tepat. Karena yang diketahui di awal uang saku kiki adalah " $x+200$ ” maka S1 menstubtisukinan apa yang diketahui kedalam persamaan yang dibuat. Meskipun persamaanya benar karena yang disubstitusikan salah, maka model matematis yang dibuat menjadi tidak tepat.

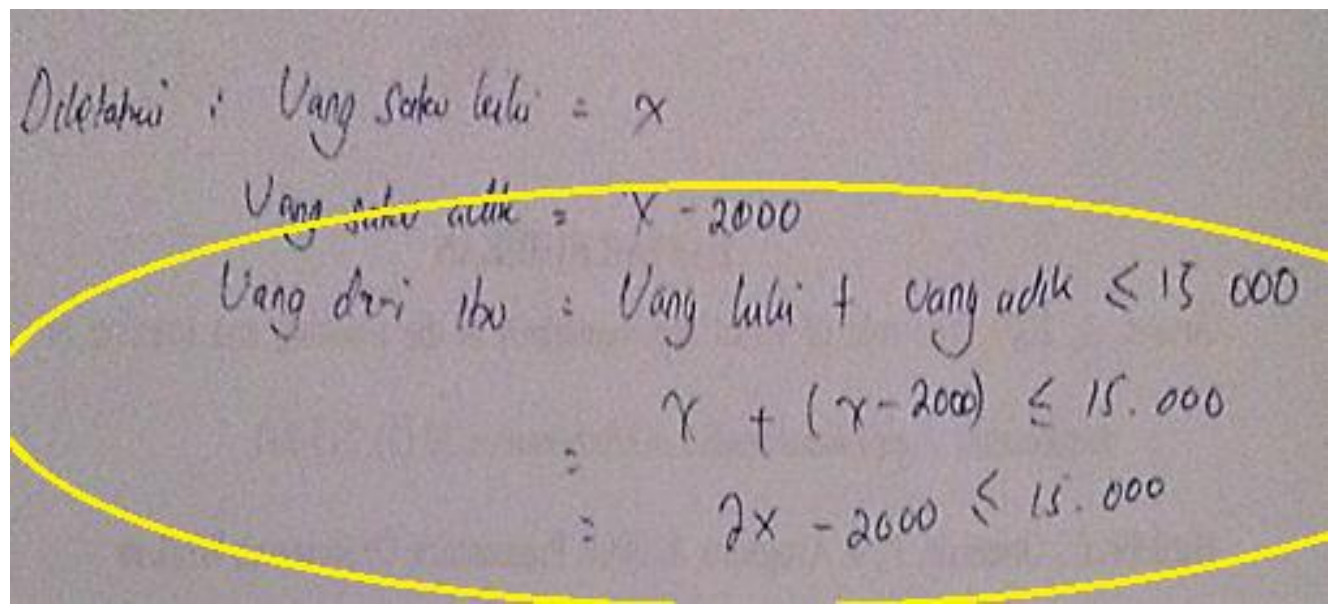

Gambar 7. Model Matematika S2

Sedangkan untuk S2, hasil pekerjaanya menunjukan bahwa S2 dapat membuat rencana penyelesaian yang tepat. Karena informasi yang didapat ketika memahami masalah sudah tepat, maka model matematis yang dibuat juga tepat. Terlihat pada 
lingkaran hitam pada gambar 7, S2 membuat model untuk menemukan nilai $x$ dengan pertidaksamaan $2 x-2000 \leq 15.000$. Berikut hasil wawancara dengan S2 :

P : "darimana kamu dapat pertidaksamaan ini ?" (menunjukan gambar yang dilingkari hitam)

S2 : “ saya jumlahkan uang saku kiki dan adiknya Pak, soalnya saya mau mencari nilai $x$ nya".

P : "kenapa mencari nilai $x$ ?"

S2 : " kan awalnya saya misalkan uang saku kiki sama dengan $x$, untuk menjawab soal kan saya harus tau nilai $x$ nya Pak".

Dari penggalan wawancara tersebut dapat disimpulkan bahwa S2 memahami rencana yang akan digunakan untuk menyelesaikan masalah. S2 menjumlahkan "uang saku kiki" dan "adiknya" untuk membuat pertidaksamaan yang akan digunakan untuk menentukan nilai $x$.

\section{Melaksanakan Perencanaan (Carry Out the Plan)}

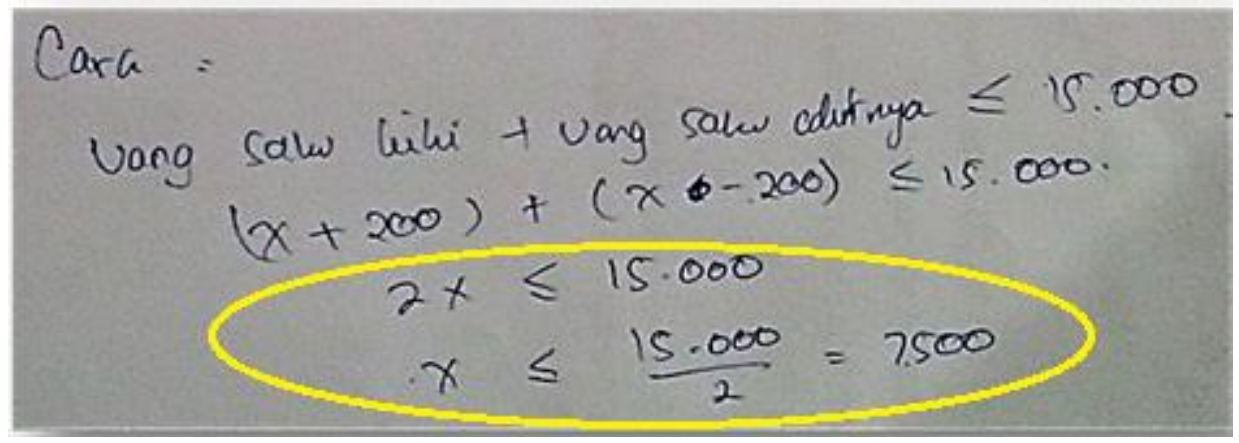

Gambar 8. Prosedur penyelesaian soal S1

Dari gambar 8 trlihat bahwa S1 melaksanakan rencanya dengan cara mengoprasikan pertidaksamaan yang dibuat sebelumnya. Namun karena kesalahan representasi dalam memahami "uang saku kiki" maka pertidaksamaan yang dibuat salah. Sehingga ketika S1 mencari nilai $x$, hasil yang didapat menjadi salah. Dari gambar yang dilingkari warna kuning dapat dilihat bahwa S1 menuliskan " $x \leq$ $\frac{15.000}{2}=7.500$ ". Peneliti menulusuri maksud dari tulisan tersebut lewat wawancara berikut:

P : "Ini maksudnya apa?” (menunjuk lingkaran kuning yang ada pada hasil pekerjaan) siswa) 
S1 : “itu maksdnya $x$ itu lebih kecil atau sama dengan 7.500 Pak”.

P : “Artinya apa itu?"

S1: "ya, berarti uang saku kiki paling banyak 7.500 Pak".

Dari sini dapat kita lihat bahwa operasi yang dilakukan S1 didalam menentukan nilai $x$ sebenarnya sudah tepat. Namun karena kesalaha representasi yang dilakukan di awal, menyebabkan hasil akhir yang didapat tidak tepat. Hal ini sesuai dengan pendapat Gil Madrona \& Samalot-Rivera (2014) yang memaparkan bahwa kesalahan yang sering dilakukan anak ketika menyelesaikan masalah persamaan atau pertidaksamaan, selain pada perhitungan aljabar, juga pada pemahaman makna kalimat yang sesuai dengan persamaan dan pertidaksamaan yang dibuat juga masih sering terjadi kesalahan. Terlihat pada hasil yang didapat oleh S1, bahwa operasi aljabar yang dilakukan S1 sudah benar, namun akibat dari kesalahan representasi yang dilakuakn ketika langkah memahami masalah, maka hasil yang didapat juga salah. Sehingga dikatakan S1 tidak memenuhi indikator R2.

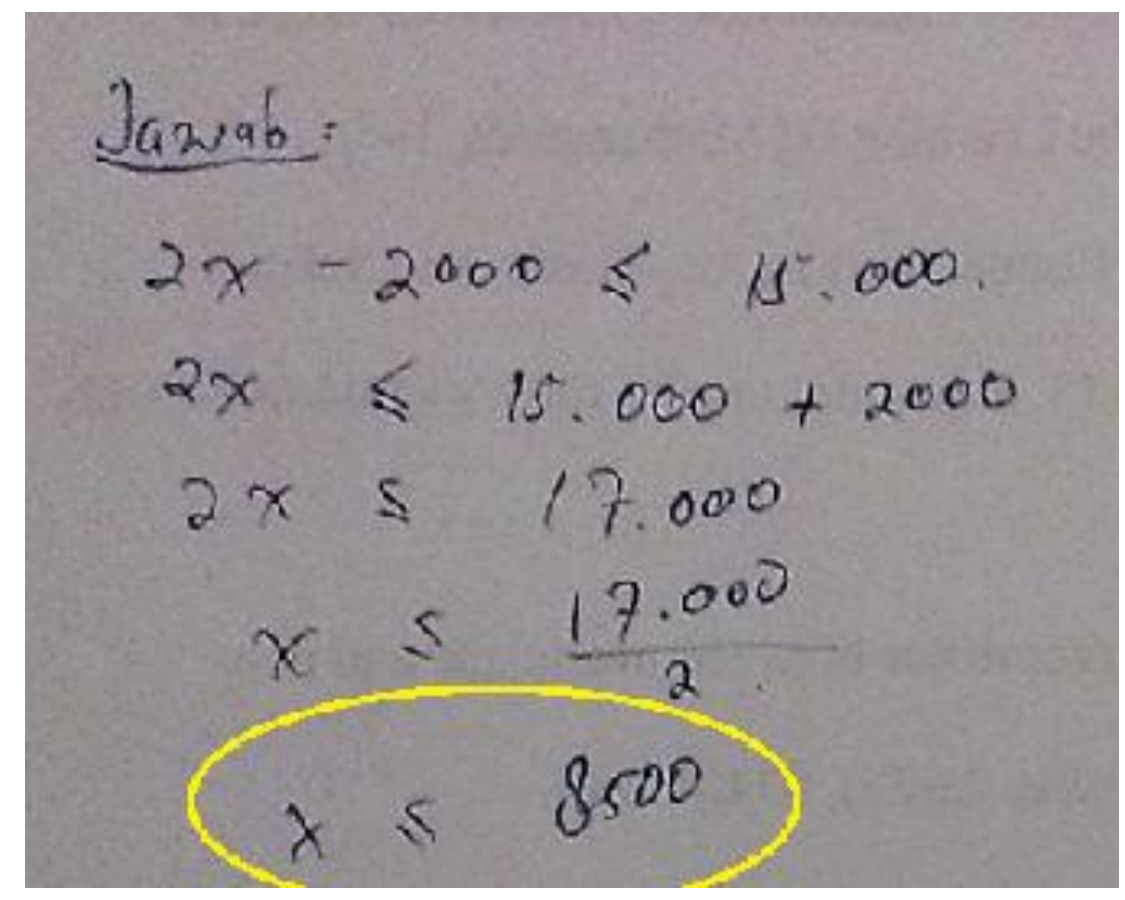

Gambar 9. Prosedur penyelesaian soal S2

Pada hasil pekerjaan S2, yang ditampilkan gambar 9, terlihat bahwa S2 dapat melaksanakan rencana penyelesaian dengan baik. Terlihat pada hasil operasi yang dilakukan S2 ,nilai $x$ yang didapat sudah benar yaitu 8.500 rupiah. Menggunakan 
model yang dibuat sebelumnya S2 berhasil menentukan nilai $x$ dengan tepat. Sehingga S2 dikatakan memenuhi indikator R2.

\section{Melihat Kembali (Looking Back)}

Hasil pekerjaan S1 sudah berhenti setelah menemukan nilai $x$, karena S1 menganggap bahwa apa yang ditanyakan soal adalah membuat model matematis dan mengetahui berapa uang saku maksimal yang mungkin diterima oleh kiki. Padahal pada tahap memahami masalah S1 sudah menuliskan bahwa yang ditanyakan soal adalah "batas maksimal uang saku kiki dan adiknya". Hal tersebut ditunjukan pada gambar berikut:

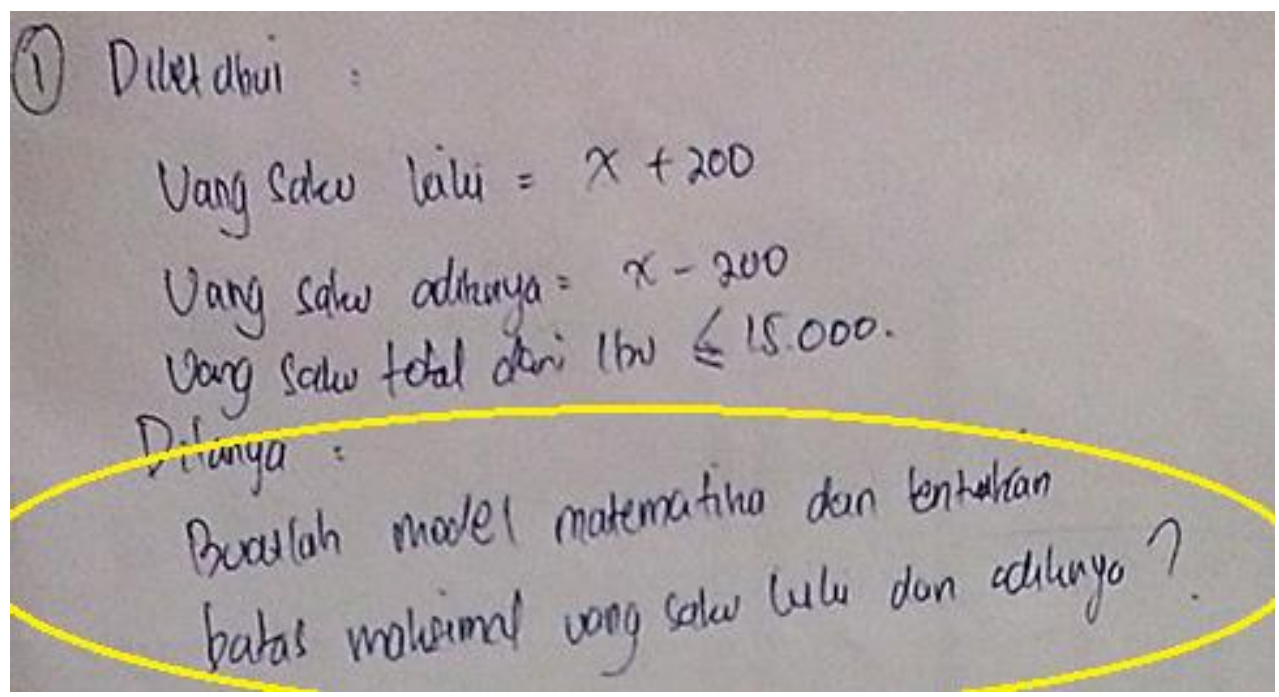

Gambar 10. Tahap Looking Back S1

Pada gambar 10, terlihat bahwa S1 sudah benar memahami informasi tentang apa yang ditanyakan dalam soal. Namun pada saat menyelesaikan masalah, S1 tidak mencari berapa banyak "uang saku adik kiki". Hal tersebut diperkuat dengan hasil wawancara berikut :

P : "kamu hanya mencari nilai $x$ saja?"

S1: "iya Pak, lupa saya kalo yang ditanyakan uang saku adiknya juga”.

P : "Kok bisa lupa?"

S1: "soalnya langsung saya kumpulkan Pak, pas udah selesai saya mau kekantin laper".

Melihat hasil wawancara tersebut dapat dilihat bahwa S1 tidak mengecek ulang jawabanya. Sehingga jawaban yang diberikan tidak sesuai dengan apa yang 
ditanyakan. Hal ini sesuai dengan pendapat dari Daniel et al. (2017) yang menyatakan pentingnya melakuakan pengecekan dalam operasi ataupun strategi ketika menyelesaikan masalah matematika. Karena S1 tidak mengecek hasil pekerjaanya, S1 melakukan kesalahan saat menyelesaikan masalah.

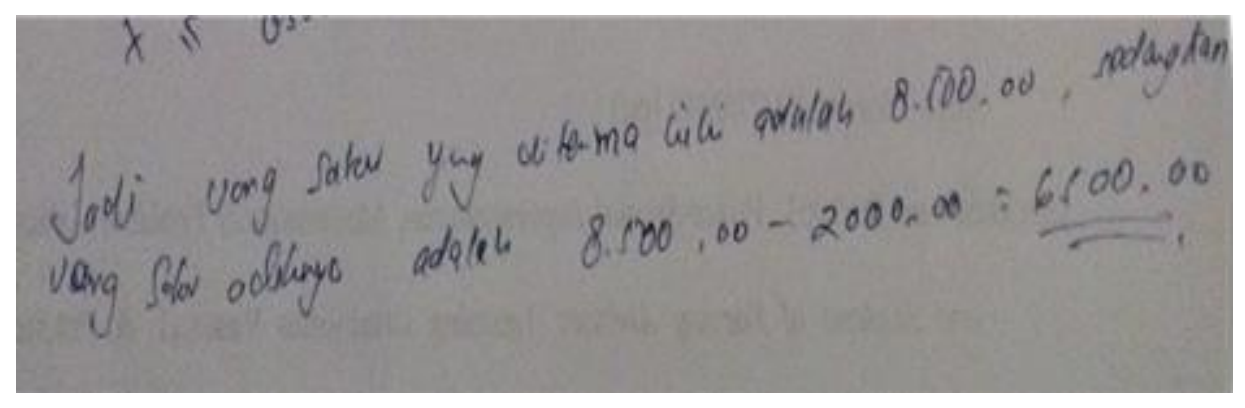

Gambar 11. Tahap Looking Back S2

Pada hasil yang terlihat pada gambar 4.2, S2 telah menyelesaikan masalah dengan baik. S2 dapat menentukan berapa uang saku yang diterima kiki dan adiknya secara tepat.

\section{KESIMPULAN}

Berdasarkan hasil penelusuran pada hasil pekerjaan S1 dan S2, maka disimpulkan bahwa:

Masih ada siswa yang merasa kesulitan menyelesaikan masalah yang berbentuk soal cerita, terbukti dengan pembahasan S1 yang menunjukan bahwa S1 tidak dapat menyelesaikan masalah dengan tepat

Kemampuan representasi akan berperan penting dalam menyelesaikan masalah soal cerita, hal ini dikarenakan soal cerita banyak mengandung kalimat-kalimat yang harus dapat di representasikan secara tepat dan sesuai dengan strategi penyelesaian. Ketika terjadi kesalahan dalam memaknai kalimat pada soal, maka mulai strategi penyelesaian sampai pada hasil juga akan salah, hal ini juga terlihat pada pembahasan S1, karena kesalahan representasi yang dilakukan di awal, maka sampai pada hasil akhir yang didapat juga menjadi salah,

Masih ada siswa yang tidak dapat menuliskan kalimat matematis secara tepat, seperti satuan, "jumlah", "rupiah", dan sebagainya, hal ini terlihat baik pada hasil pekerjaan S1 maupun S2, dengan demikian dapat dikatakan bahwa representasi yang dibuat oleh siswa masih belum sempurna. 


\section{DAFTAR PUSTAKA}

Barata, M., \& Pinto, P. R. (2019). Representations of Thompson groups from Cuntz algebras. Journal of Mathematical Analysis and Applications, 478(1), 212-228. https://doi.org/10.1016/j.jmaa.2019.05.028

Berry, R. Q., Bol, L., \& McKinney, S. E. (2009). Addressing the principles for school mathematics: A case study of elementary teachers' pedagogy and practices in an urban high-poverty school. International Electronic Journal of Mathematics Education, $4(1), 1-22$.

Creswell, J. W. (2014). Research Design: Qualitative, Quantitative and Mixed Methods Approaches (4th ed.). SAGE.

Daniel, J. R., Silva, R. R., Santos, A. J., Cardoso, J., Coelho, L., Freitas, M., Ribeiro, O., Brück, N., \& Gutenberg-universität, J. (2017). Perception Accuracy of Affiliative Relationships in Elementary School Children and Young Adolescents. Frontiers in Psychology, 8(11), 55-65. https://doi.org/10.3389/fpsyg.2017.01936

Desoete, A. (2019). Mathematics and metacognition in adolescents and adults with learning disabilities. International Electronic Journal of Elementary Education, 2(1), 82-100. www.iejee.com

Gil Madrona, P., \& Samalot-Rivera, A. (2014). Improving Social Skills through Physical Education in Elementary 4th Year. American Journal of Sports Science and Medicine, 2(6A), 5-8. https://doi.org/10.12691/ajssm-2-6A-2

Hidayati, V. R., Maulyda, M. A., Gunawan, G., Rahmatih, A. N., \& Erfan, M. (2020). System of Linear Equation Problem Solving: Descriptive-Study about Students' Mathematical Connection Ability. Journal of Physics: Conference Series, 1594, 012042. https://doi.org/10.1088/1742-6596/1594/1/012042

Indrianto, N., \& Nurul Fatmawati, D. (2020). Teacher Skills in Classroom Management in Thematic Learning in Elementary Schools. Journal AL-MUDARRIS, 3(1), 15-34. https://doi.org/10.32478/al-mudarris.v3i1.335

Jeannotte, D., \& Kieran, C. (2017). A conceptual model of mathematical reasoning for school mathematics. Educational Studies in Mathematics, 35(4), 235-267. https://doi.org/10.1007/s10649-017-9761-8

Kaur, B. (2014). MATHEMATICS EDUCATION IN SINGAPORE - AN INSIDER'S PERSPECTIVE. Journal on Mathematics Education, 5(1). https://doi.org/10.22342/jme.5.1.1444.1-16

Komatsu, K. (2016). A framework for proofs and refutations in school mathematics: Increasing content by deductive guessing. Educational Studies in Mathematics. https://doi.org/10.1007/s10649-015-9677-0

Kosko, K. W., \& Gao, Y. (2017). Mathematical Communication in State Standards Before the Common Core. Educational Policy, 31(3), 275-302. https://doi.org/10.1177/0895904815595723

Maulyda, A. M., Hidayati, V. R., Erfan, M., Umar, \& Sutisna, D. (2020). Kesalahan Komunikasi Matematis (Tertulis) Siswa Ketika Memahami Soal Cerita. Jurnal Karya Pendidikan Matematika, 7(1), 1-7. 
Maulyda, M. A., Hidayati, V. R., Rosyidah, A. N. K., \& Nurmawanti, I. (2019). Problemsolving ability of primary school teachers based on Polya's method in Mataram City. PYTHAGORAS: Jurnal Pendidikan Matematika, 14(2), 139-149. https://doi.org/https://doi.org/10.21831/pg.v14i2.28686

Morphew, J. W., Gladding, G. E., \& Mestre, J. P. (2020). Effect of presentation style and problem-solving attempts on metacognition and learning from solution videos. Physical Review Physics Education Research, 16(1), 10104. https://doi.org/10.1103/PhysRevPhysEducRes.16.010104

Pantaleon, K. V., Juniati, D., \& Lukito, A. (2018). The oral mathematical communication profile of prospective mathematics teacher in mathematics proving. Journal of Physics: Conference Series, 1108, 1-6. https://doi.org/10.1088/1742$6596 / 1108 / 1 / 012008$

Santoso, B., Putri, D. H., \& Medriati, R. (2020). Upaya Meningkatkan Motivasi Belajar dan Kemampuan Pemecahan Masalah Siswa Melalui Model Problem Based Learning Berbantu Alat Peraga Konsep Gerak Lurus. Jurnal Kumparan Fisika, 3(1), 11-18.

Sukoriyanto, S., Nusantara, T., Subanji, S., \& Chandra, T. D. (2016). Students' Errors in Solving the Permutation and Combination Problems Based on Problem Solving Steps of Polya. International Education Studies, 9(2), 11. https://doi.org/10.5539/ies.v9n2p11

The National Council of Teachers of Mathematics. (2000). Principles and Standards for School Mathematics. The National Council of Teachers of Mathematics, Inc.

Walk, L., \& Lassak, M. (2017). Making Homework Matter to Students. Mathematics Teaching in the Middle School, 22(9), 546-553.

Yusnia, D. (2018). Analysis The Ability of Students Problem-Solving on Counting Operations of Algebra Form. MUST: Journal of Mathematics Education, Science and Technology, 3(1), 1. https://doi.org/10.30651/must.v3i1.1017 